\title{
Multi-causal and integrated assessment of sustainability: the case of agriculturization in the Argentine Pampas
}

\author{
David Manuel-Navarrete - Gilberto C. Gallopín • Mariela Blanco • \\ Martín Díaz-Zorita · Diego O. Ferraro · Hilda Herzer · Pedro Laterra • \\ María R. Murmis · Guillermo P. Podestá · Jorge Rabinovich • \\ Emilio H. Satorre · Filemón Torres · Ernesto F. Viglizzo
}

Received: 29 August 2007/Accepted: 19 November 2007/Published online: 11 December 2007

(C) Springer Science+Business Media B.V. 2007

\begin{abstract}
Assessing the sustainability of complex development processes requires multi-causal and integrated analyses. We develop a system-based methodology, rooted
\end{abstract}

Readers should send their comments on this paper to: BhaskarNath@aol.com within 3 months of publication of this issue.

D. Manuel-Navarrete $(\bowtie)$

Department of Geography, Kinǵs College London, Strand, London WC2R 2LS, UK

e-mail: david.manuel_navarrete@kcl.ac.uk

G. C. Gallopín

Tte. Gral J.D. Perón, Piso 5, Buenos Aires 1040, Argentina

e-mail: gilberto.gallopin@ fibertel.com.ar

M. Blanco

Centro de Estudios e Investigaciones Laborales (CEIL-PIETTE) CONICET, Saavedra 15 piso $4^{\circ}$, Capital Federal CP: 1083, Argentina

e-mail: mblanco@ceil-piette.gov.ar

M. Díaz-Zorita

CONICET and Department of Plant Production, Faculty of Agronomy, University of Buenos Aires,

(1417) Av. San Martín 4457, Buenos Aires, Argentina

e-mail: mdzorita@agro.uba.ar

D. O. Ferraro

IFEVA, Cátedra de Cerealicultura, Departamento de Producción Vegetal, Facultad de Agronomía, UBA/CONICET, Av. San Martín, 4453, C1417DSE Ciudad de Buenos Aires, Argentina

e-mail: ferraro@agro.uba.ar

H. Herzer

CENTRO estudios sociales y ambientales, Av. Pte. Roque Saenz Peña 1142, 5 1035 Buenos Aires,

Argentina

e-mail: cesam@datamarkets.com.ar

P. Laterra

Faculty of Agricultural Sciences, National University of Mar del Plata-INTA Balcarce, CC 276, 7620

Balcarce, Argentina

e-mail: platerra@balcarce.inta.gov.ar 
in interdisciplinary discussion and consensus building between 15 experts, to construct a multi-causal diagram which examines the sustainability of the Argentine Pampaś process of agriculturization. The resulting diagram includes 25 factors and provides a big-picture of the multiple dimensions and interrelations affecting sustainability. According to this examination, the increasing concentration of production and the incorporation of technological innovations, triggered by economic and institutional factors, are the cause of environmental distresses and social changes, whose consequences for sustainability are still highly disputed. Nevertheless, the symptoms of both environmental and social unsustainability are more evident in the case of the extraPampean regions than in the Pampas. This suggests that the Pampean agriculture model should not be transferred to these regions without substantial modifications. The experts did not reach consensus on whether the agriculturization process is overall sustainable or unsustainable. Lack of consensus revolved mainly around opposing perspectives regarding the significance of the threats to environmental sustainability. The magnitude of socio-distributive unbalance and loss of rural jobs were also contentious. Yet, the paper shows how the exercise of building a joint causal diagram was undoubtedly helpful for linking piece-meal disciplinary facts, brought in from all fronts, into a comprehensive and coherent picture.

Keywords Agriculturization - Sustainability - Pampas · Multi-causal diagrams · Integrated assessment $\cdot$ Syndromes of global change

M. R. Murmis

Apoyo al Programa de Medianas Donaciones del GEF en Argentina, GEF/PNUD, Piedras 482, 2 "G", Buenos Aires C1070AAJ, Argentina

e-mail: murmismaria@fibertel.com.ar

G. P. Podestá

University of Miami, Rosenstiel School of Marine and Atmospheric Science, 4600 Rickenbacker Causeway, Miami, FL 33149-1098, USA

e-mail: gpodesta@rsmas.miami.edu

J. Rabinovich

Center for the Study of Parasites and Vectors (CEPAVE), National University of La Plata,

Calle 2 No. 584, 1900 La Plata, Province of Buenos Aires, Argentina

e-mail: jorge@ecopaedia.com.ar

E. H. Satorre

Cátedra de Cerealicultura, Facultad de Agronomía, University of Buenos Aires, Av. San Martín 4453, P. O. Box C1417DSE, Buenos Aires, Argentina

e-mail: satorre@agro.uba.ar

F. Torres

CEO Group (Consultants on Economy and Organization), Hipólito Yrigoyen 785-5 M,

1086 Buenos Aires, Argentina

e-mail: grupoceo@grupoceo.com.ar

\section{E. F. Viglizzo}

Environmental Management Program, National Institute for Agricultural Technology (INTA La Pampa), Av. Spinetto 785, 6300 Santa Rosa, La Pampa, Argentina

e-mail: evigliz@cpenet.com.ar 


\section{Introduction}

The Pampas of central-eastern Argentina is a plain of more than 50 million hectares whose high fertility and productivity provides significant comparative advantages for agriculture production (Hall et al. 1992). During the last 25 years, this region has experienced a process of "agriculturization" characterized by a strong and continuous increase in the land area dedicated to crop growing.

Agriculturization in the Pampas began slowly in the 1960s with an increase in the cultivation of areas previously dedicated to cattle ranching. At the end of the 1970s, the process started to expand towards extra-Pampean regions with the transfer of capital, technology, and new cultivation schemes to non-agriculture areas. Since the early 1990s, structural economic changes fostered investment in technology which played a major role in land-use changes in the Pampas. The most dramatic technological innovation in Argentine agriculture is the 1996 introduction of genetically modified soybeans tolerant to glyphosate, an herbicide that controls weeds but does not affect soybeans (Trigo and Cap 2003; Qaim and Traxler 2005).

The expansion of soybean in Argentina has been impressive: introduced in the early 1970 s, the soybean area (production) reached 5.1 Mha (11 Mtons) in 1990 and exploded to 14.0 Mha (38 Mtons) in 2005, displacing other crops, pastures, and forests. Soybean currently is more profitable than other crops, requires less investment (due to lower costs associated with genetically modified varieties) and labor, and has significantly lower production risk than alternative enterprises. Nevertheless, potential conflicts are arising. While Argentina enjoys the economic benefits of soybean exports ( $\approx$ \$US4.5 B in the first half of 2006; $20 \%$ of all exports), worries are growing about soybean monoculture (Leteinturier et al. 2006), and the expansion of cultivated land over natural ecosystems (Pengue 2005). Clearly, a system in which over half of the area is dedicated to a single crop is highly brittle to shocks or surprises such as large climate anomalies or price fluctuations.

The main argument of this paper is that assessing the sustainability of complex processes, such as agriculturization, requires multi-causal and integrated analyses carried out by experts from multiple disciplines. The need for an interdisciplinary and systemic approach is common place in the sustainable development literature (Kates et al. 2001). However, both the development of robust methodologies for coordinating multiple knowledges, and the implementation of successful experiences of interdisciplinary collaboration are not yet consolidated. This paper presents a successful experience of interdisciplinary collaboration and illustrates some of the obstacles for carrying out this kind of exercises. Overcoming such obstacles is crucial to build a sound understanding of human-nature interactions.

The next section outlines the steps followed for assessing the sustainability of agriculturization in the Pampas and extra-Pampean regions. The outcome of this assessment, expounded in the Sect. 3, constitutes an integrated view of the process of agriculturization agreed by a group of renowned experts in the Pampas agroecosystems. In the Sect. 4, we explore how the experts' common view on "what is happening" in the Pampas, and "why it is happening", was not enough for reaching consensus on a diagnosis of sustainability. Nevertheless, the exercise proved to be useful for explicitly acknowledging the major points of disagreement and identifying the main scientific uncertainties. The transparent characterization, from multiple disciplinary viewpoints, of the causal dynamics involved in sustainability may facilitate communication among experts, decision-makers, and lay people. It can also help to design integrated policies and detect win-win opportunities. We argue that this type of exercises is crucial for building useful and usable knowledge for sustainability policy-making. 


\section{Methodology: building causal diagrams of human-nature interactions through interdisciplinary collaboration}

We developed a system-based methodology for building a causal diagram of agriculturization in the Argentine Pampas (including the provinces of Buenos Aires, Entre Ríos, east of La Pampa, south of Córdoba and Santa Fe), and extra-Pampean regions (north of Córdoba and Santa Fe, Corrientes, Chaco, Formosa, Santiago del Estero, and east of Salta) (Fig. 1). If this causal complex could be detected in other regions of the world, it would constitute a Sustainable Development Syndrome in the sense defined by Manuel-Navarrete et al. (2007), as an adaptation of the "syndromes of global change" concept proposed in Lüdeke et al. (2004).

The term 'syndrome' refers to a typical co-occurrence of different symptoms that describe complex natural and/or anthropogenic dynamic phenomena. Syndromes are more than causal networks of specific situations. For instance, it is plausible that similar agriculturization patterns are replicated in the Brazilian Cerrado, the South of Paraguay, Southeast of Bolivia, and Southwest of Uruguay. This hypothesis should be examined through place-based assessments, similar to the one presented here, carried out for these regions.

Our system-based methodology consists of a guided process of interdisciplinary discussion and consensus-building encompassing three major stages:

1. Organization of a workshop with a group of experts from a highly diverse set of disciplines (in this Pampas-case, 15 experts from the fields of ecology, geography, economy, sociology, biology, agronomy, soil science, and climatology were convened).

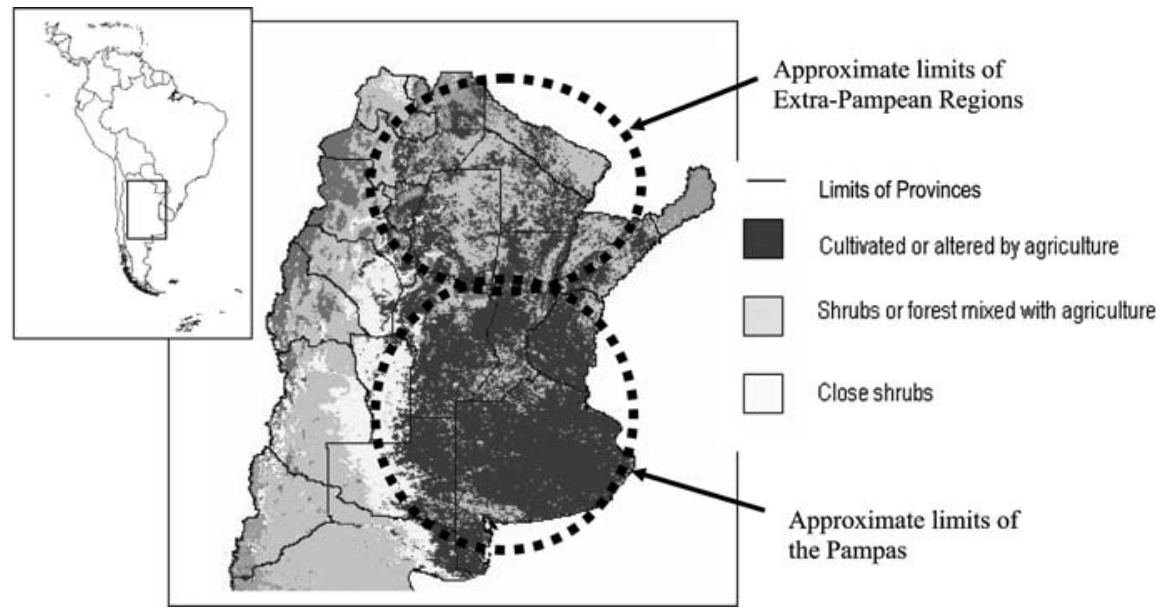

Fig. 1 Location of the Pampas and extra-Pampean regions and land use in Central and Northern Argentina (1990-1996). Source: SIGESALC, ECLAC, based on data from the International Geosphere-Biosphere Programme 
- The group of experts is separated into two subgroups to facilitate exhaustive discussion and active participation by all experts; subgroup composition, however, is designed to preserve the diversity of perspectives within each subgroup.

- Each subgroup identifies the most relevant factors involved in the sustainability of the process under analysis (in the Pampas case it was very useful to count on a previous exploration of the agriculturization causal structure prepared by Rabinovich and Torres (2004) as a starting point for discussion).

- Each subgroup discusses the plausible causal relations among the factors identified, specifying the uncertainties involved in such associations.

- In plenary session, each subgroup presents its results in the form of a causal diagram. The generalization of both diagrams into a joint one is explored (in the Pampas case, the two diagrams were similar enough as to be unified into a consensus vision of the agriculturization process).

2. Post-workshop electronic mail communications among the experts, using the agreed causal diagram as a base for discussion, to:

- Consolidate the meaning of each factor and causal relationship,

- Seek consensus regarding a sustainability assessment of the process analyzed.

3. Preparation of a report based on the workshop's recorded discussion and the subsequent e-mail communications (see Manuel-Navarrete et al. (2005)).

The results of this process were re-examined and corroborated through a literature review and data search in order to further support the experts' accounts with available evidence.

Finally, the diagram was used as the base for discussing policy integration in a subsequent political workshop with 5 high-ranking officials from several ministries of the Argentine government (see Manuel-Navarrete and Gallopin 2007).

\section{Results: Causal diagram of agriculturization in the Argentine Pampas and extra- Pampean regions}

The multi-causal diagram in Fig. 2 includes 25 factors which, according to the 15 convened experts, characterize the sustainability of the agriculturization process in the Pampas. In this section, we describe these factors and their interrelations by following the structure of the expertś diagram.

\subsection{The central role of the concentration of production and management}

A key factor leading to the process of agriculturization is the increasing concentration of agriculture production and management (Fig. 2, Factor [1]). According to the Argentina's National Institute of Statistics and Census, changes in land tenure between 1988 and 2002 showed a strong concentration in the Pampas, with the average area of a production unit increasing from 400 ha to 533 ha (SAGPyA 2002). The smaller production units $(<500 \mathrm{ha})$ dropped by $34 \%$ in number and $26 \%$ in total area. In contrast, production units between 2.500 and 10.000 ha increased by $6 \%$ in number and $5 \%$ in area, while those $>10.000$ ha increased by $13 \%$ in number and $14 \%$ in area. 


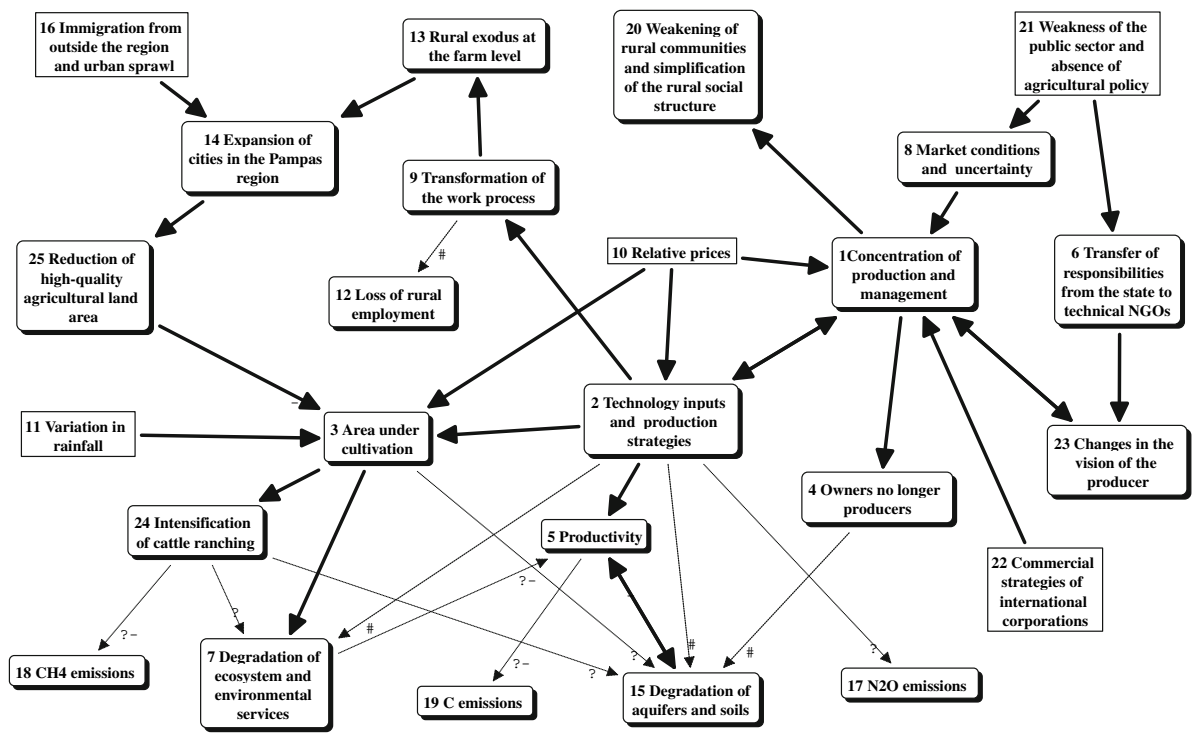

Fig. 2 Causal Diagram examining the sustainability of agriculturization in the Argentine Pampas and extraPampean regions. Note: The continuous lines indicate monotonic positive relationships (in other words, if the variable of origin grows or diminishes, the recipient variable changes in the same direction). The lines with a negative sign indicate monotonic negative relationships (in other words, if the variable of origin grows or diminishes, the recipient variable changes in the opposite direction). The dotted lines with question marks denote hypothesized causal relationships that are not confirmed. The dashed lines with number signs denote disputed causal relationships. Each line denotes a direct effect of one variable on another, not the effects via third variables of the graph. Source: Adapted from Manuel-Navarrete et al. 2005

Production and management concentration facilitates the adoption of input-oriented (machinery, fertilizers, pesticides), and process-oriented (management systems with a high component of information and knowledge such as no-tillage or precision agriculture) technologies (factor [2]). For instance, the use of fertilizers in the Pampas was negligible in the 1970s and very low during the 1980s (Flores and Sarandon 2002). By 2002 the use of fertilizers in the Pampas for wheat, soybean, and corn reached 710,000 tones (FAO 2004; Table 1). Likewise, the adoption of no-till agriculture covered in 2000 almost $50 \%$ of the total cultivated area (Satorre 2001; Salvador 2001; Trigo 2005) (Fig. 3). In turn, factor [2] contributes to creating economies of scale which favor [1]. Therefore, a positive feedback loop exists between factors [1] and [2], in which increasing one leads to increasing the other and vice-versa.

A second consequence of [1] is its effect on the socio-political weakening of rural communities and, in general, the simplification of rural social structures [20]. Agriculture social structures lose their small and medium farmers base and, as a consequence,

Table 1 Percentage of farmers using fertilization by crop in the Pampas (1995-2001)

Source: Adopted from FAO (2004)

\begin{tabular}{lll}
\hline Crop & Average \% 1995-1997 & Average \% 1999-2001 \\
\hline Wheat & 64 & 78 \\
Corn & 55 & 75 \\
Forage & 21 & 61 \\
Soybean & 6 & 18 \\
Sunflower & - & 31 \\
\hline
\end{tabular}




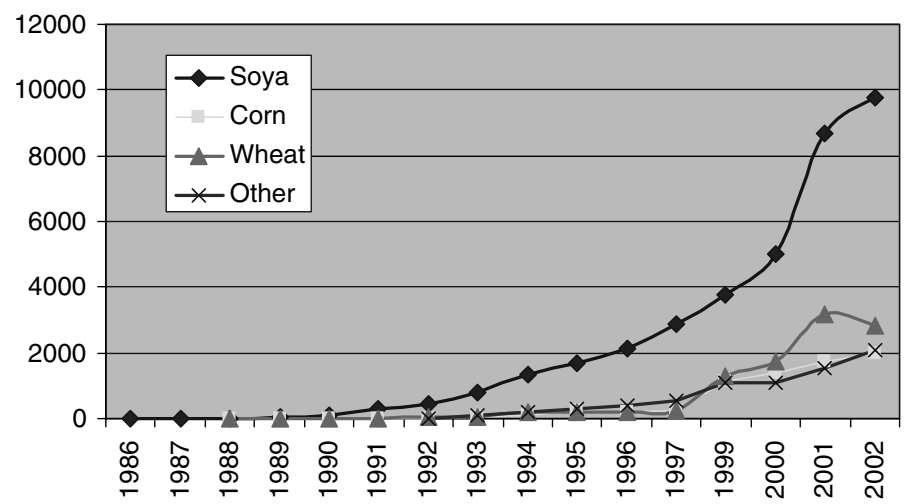

Fig. 3 Area cultivated under zero-tillage in Argentina (1,000 ha). Source: Argentine Association of Producers under no-tillage (AAPRESID). Retrieved 18 July 2007 from http://www.aapresid.org.ar/apadmin/ img/upload/evolucion.xls

traditional knowledge, rural culture, particular ways of living, and production schemes. Agriculture census shows that from, 1988 to, 2002 around 53.360 small farms, representing around $30 \%$ of the total existing in 1988, were merged into bigger farms.

A third consequence of [1] is that, in many cases, much of the area planted in the Pampas is not owned by those cultivating it. [4]. It has been estimated that about $75 \%$ of grains are produced by land leaseholders (Pengue 2005). In addition, the process of production gets increasingly professionalized and endowed with managerial tasks carried out by contractors. The environmental effects [15] of this dissociation are barely known. However, two alternative hypotheses can be set out:

A first hypothesis holds that when land is leased to a company or a sowing pool (speculative investment funds for large-scale production when crop prices are high), there are strong incentives to maximize short-term profits via agriculture and may discourage sustainable practices such as ecologically sound crop rotations (Carolan 2005; Leteinturier et al. 2006). According to the observations from some of the experts, the relationship between land tenure and degradation is more evident in the case of extra-Pampean regions, where large tracks of public lands are cultivated, sometimes unlawfully, with soybean monoculture leading to high rates of soil degradation.

The opposite hypothesis holds that as land becomes more commoditized, competition among farmers for rental land increases and, consequently, land tenants are pressed by landowners to carry out a sustainable agriculture management, including the conservation of soil productivity. Thus, according to this hypothesis, high competition for land renting is acting as an incentive to sustainable (or at least adequate) management. Another element supporting this hypothesis is the observation that big firms, renting large tracks of land, tend to incorporate more sophisticated management systems, which allow for more effective environmental management when not in conflict with productivity and profitability (Satorre 2005).

\subsection{Factors leading to the concentration of production and management}

A main starting point causing production and management concentration [1] is the weakness of the public sector and the lack of agriculture policies [21]. This, in turn, 
empowers the role of markets and increases business uncertainty [8]. Both [21] and [8] promote comparative advantages of large farmers and thus reinforce [1]. In addition, [21] results in a tacit transfer of responsibilities, such as strategic production decisions, from the State to technical NGOs and agribusiness corporations [6]. During the 1990s, the dramatic weakening of the government institutions linked to agriculture policies, such as the dismantlement of some of the services (e.g., extension) offered by the National Institute of Agriculture Technology, increased the relevance of private actors in terms of technology diffusion and professional assistance (Blake et al. 2002). This is significant for sustainability because these actors, unlike the public sector, are not mandated to defend the common good and public interest.

The increasing power of farmers' associations [6] and the scaling up of production and management [1] induce a change of worldview amongst large farmers [23]. These farmers tend to become knowledge-intensive professionals with a strong agribusiness and entrepreneurial culture (Bisang 2003). Technical NGOs actively promote the diffusion of this worldview that, in turn, favors [1].

Another factor determining [1] is relative price changes [10]. In particular, prices between alternating crops, agriculture inputs, and agriculture commodities. For instance, if commodities' prices decrease, farmers will have, depending on fertilizer prices, an incentive for intensification (thus compensating lower commodity prices by increasing productivity). In this situation, farmers with higher available capital will enjoy competitive advantages. As a consequence, some small and medium farms may even end up out of business (Piñeiro and Villarreal 2005).

Finally, the commercial strategies of international corporations [22] promotes [1] by offering comparative advantages to large farmers for purchasing agricultural inputs and machinery, and providing significant technical assistance to large farmers throughout their wide networks of products' distribution (Bisang 2003). Consistent with the process of trade liberalization implemented in Argentina during the 1990s, the commercial strategies of international corporations became highly influential and adopted roles that go far beyond their traditional role as providers of agricultural inputs and technologies.

\subsection{Adoption of new technologies trigger agriculture expansion and intensification}

The factor "Technology, inputs, and production strategies" [2] (including intensification, monoculture versus rotations, conventional tillage versus no-till, mechanization, election of planting dates and other management practices) is the main direct cause of the expansion of the area under cultivation [3].

In the Pampas, the cultivated area grew at the expense of areas used for either cattle ranching, or cattle and grain rotations (Fig. 4). Between 1988 and 2002 the area cropped increased an average of $10 \%$, while pasture area was reduced by 4 million ha (SAGPyA 2002). In extra-Pampean regions, in contrast, agriculture expansion takes over native ecosystems and areas occupied by traditional crops. In these regions, the area planted with soybean has increased from, 200,000 ha in 1990 to around 3,000,000 ha in 2005 (SAGPyA 2005), in accordance with the present high rates of deforestation of most extra-Pampean provinces (Table 2).

Relative prices between inputs and commodities influence both [2] and [3]. For instance, a higher increase of commodity prices allows farmers to invest part of their benefits in cultivating new areas. This trend is strengthened by the lack of investment options outside the agriculture sector. The increase of the area cultivated with soybean 


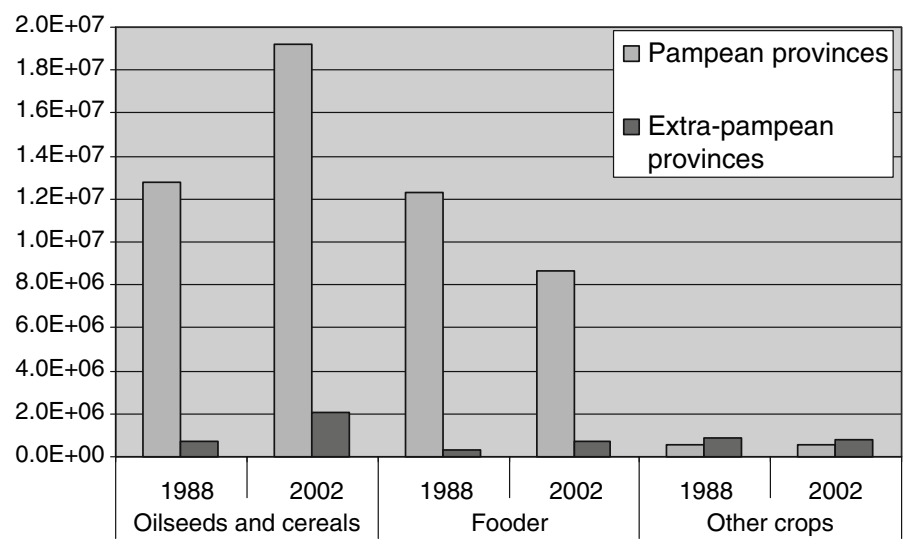

Fig. 4 Land use changes in the Pampas and extra-Pampean provinces (ha). Note: Pampean provinces: Buenos Aires, Córdoba, Entre Ríos, Santa Fe; Extra-Pampean provinces: Chaco, Corrientes, Formosa, Santiago del Estero. Source: (SAGPyA 2002)

Table 2 Ranking of the Argentine provinces with highest deforestation rates (1998-2002)

\begin{tabular}{lll}
\hline Province & Deforestation (Hectares) & Geographic location \\
\hline 1st: Santiago del Estero & 306.055 & Extra-Pampean province \\
2nd: Salta & 194.389 & Half of the province is extra-Pampean \\
3rd: Córdoba & 121.107 & Half Pampean and half extra-Pampean \\
4th: Chaco & 117.974 & Extra-Pampean province \\
5th: Tucumán & 22.171 & Neither Pampean nor extra-Pampean \\
6th: Formosa & 20.112 & Extra-Pampean province \\
7th: Jujuy & 6.174 & Neither Pampean nor extra-Pampean \\
\hline
\end{tabular}

Source: Report on Deforestation in Argentina, Dirección de Bosques, SAyDS, oct., 2004

under no-tillage can be correlated with the relative prices between glyphosate, which is an essential input for this cultivation scheme, and diesel fuel, an essential input for traditional tillage. The cost index glyphosate/diesel for a liter of each product decreased from 170 in 1982 down to 5 in 2000 (AACREA 2001).

Another factor causing agriculture expansion is the variation of rainfall patterns [11] observed since the mid 1970s. Average annual precipitation has increased by $180 \mathrm{~mm}$ in the Pampas since 1967 (although it started to decline smoothly in the last 5 years) (Messina 1999). This increase has provoked a 100-km westward displacement of the $600 \mathrm{~mm}$ isohyets in relation to its average position observed during the 20th Century (Sierra et al. 1994). Other studies correlate rainfall with production (Viglizzo et al. 1997), showing a coincidence between agriculturization and rainfall increase, particularly in marginal drier areas.

Factor [3] leads to a significant change in cattle ranching practices with a reduction of grassland areas (Fig. 4) and a direct impact on landscape structures (Ghersa and Ghersa 1991). Associated with the increase in agricultural area, there is a parallel process of concentration and intensification of cattle production [24]. It is important to note that overall cattle production is not significantly declining (Fig. 5). However, it is intensified and increasingly decoupled, in terms of productive organization, from cultivation activities. 


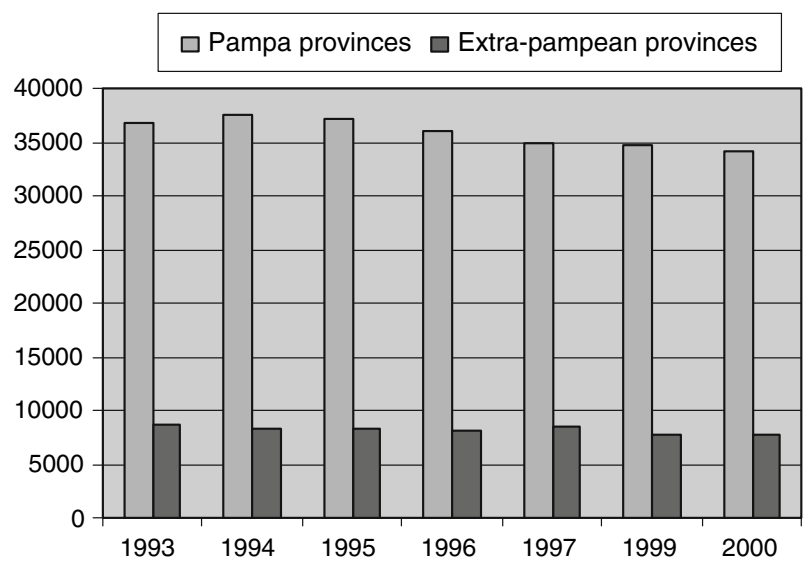

Fig. 5 Heads of cattle in Pampean and extra-Pampean provinces (thousands). Note: Pampean provinces: Buenos Aires, Córdoba, Entre Ríos, Santa Fe; Extra-Pampean provinces: Chaco, Corrientes, Formosa, Santiago del Estero. Source: SAGPyA (2002)

\subsection{Environmental effects of agriculturization}

The expansion of the area under cultivation [3] has a significant influence over ecosystems and environmental services [7]. Degradation of services related to erosion control, and the regulation of water and nutrients cycles were reported in the entire area, but are more severe in the extra-Pampean regions (Viglizzo and Frank 2006). Agricultural expansion is taking over riparian zones and removing wire fences which used to function as biological corridors and ecotones (i.e. areas of transition between two adjacent ecological communities). The conversion of grasslands into monocultures has dramatically reduced the number of species and the population abundance of birds and mammals in the region during the last 100 years (Bilenca 2000). Some species of rodents are exceptions to this rule and have reached pest levels (Bilenca and Kravetz 1995). Studies on pesticides and fertilizers suggest that water pollution is endangering aquatic species (Costa et al. 2002; Miglioranza et al. 2003; Jergentza et al. 2005).

The increase in the use of glyphosate, attributed to production schemes based in notillage with Round-up Ready (RR) soybean, is often quoted as a main source of environmental impacts (Branford 2004) (Fig. 6). Average use of glyphosate increased from 2 liters/ha to more than 8 between 1991 and 1999 (Morales 2001).

Some studies have examined the impacts of the expansion of the area under cultivation [3] over the nutrient, water and biological cycles (Viglizzo et al. 2001). These studies point to losses of ecological stability, which are partially compensated by increasing anthropogenic subsidies (e.g. fertilization). An integrated assessment carried out to evaluate the effects of pesticides on agroecosystems supported the idea of a trade-off between a reduction of erosion risk (e.g. no-tillage systems) and a concomitant increase of the negative effect of pesticides (i.e. higher toxicity of the pesticides used) (Ferraro et al. 2003).

Despite the fact that knowledge of the environmental impacts of agriculture is steadily progressing, critical uncertainties still persist. The use of herbicides, insecticides and fungicides in the Pampas in the last 15 years is highly complex and not exclusively linked with RR soy. In fact, the global share of pest control products used for soybean (versus 


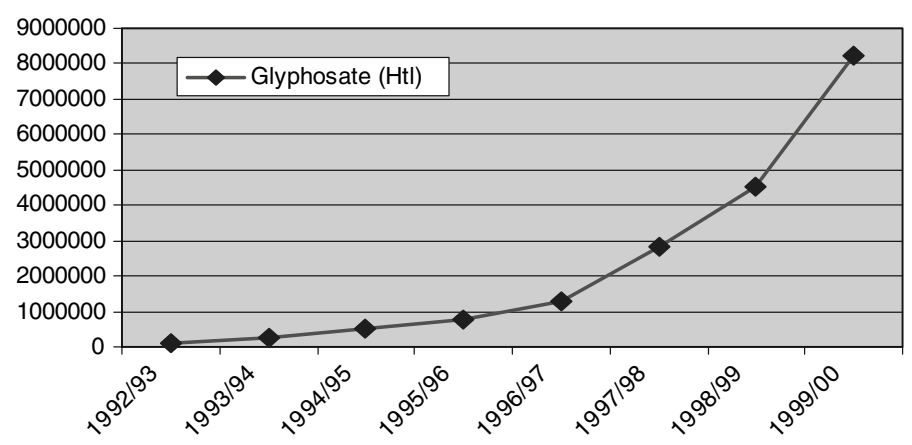

Fig. 6 Glyphosate consumption in Argentina (Hectolitres). Source: Bisang (2003)

other crops) decreased from 70 to $55 \%$ for this period (Díaz-Zorita 2005). In addition, there are no conclusive studies regarding the impact of increasing use of glyphosate versus the decline of other herbicides, such as atrazine (presently substituted by glyphosate).

During the workshop, experts could not agree on the net environmental impacts of technological change and production strategies [2]. On the one hand, the adoption of no-till agriculture seems to have had a positive effect on soil fertility by increasing organic matter content and reducing erosion rates (Díaz-Zorita et al. 2002). On the other hand, no-tillage is usually coupled with soybean monoculture, which has negative effects in both organic matter content, and the chemical properties of soil (Casas 2005).

Soil degradation [15] is decreasing productivity [5] in some areas of the Pampas and particularly in the extra-Pampean region. Flores and Sarandon (2002) estimated that 23 million tones of nutrients were lost in the Pampas between 1970 and 1999, of which soybean was responsible for about $46 \%$, wheat for $28 \%$, and corn $26 \%$. Yet, nutrient loss rate decreased during the 1990 s mainly due to no-tillage agriculture and the use of fertilizers.

A survey in the driest areas of the Pampas between 1990 and 1994 demonstrated that corn is the crop most sensitive to soil erosion and wheat the least sensitive (Irurtia and Mon 2000). Severe erosion (between 20 and 70 t/ha/year) reduced by 36,30 and $44 \%$ the yields of soybean, wheat and corn, respectively, in relation to no erosion. There is some evidence that intensive land use in specific areas of the Pampas has reduced the structural stability of soil aggregates (Maddonni et al. 1999). Soil degradation might be even more serious, as its consequences on yields are often masked by the availability of new genetic materials and new agricultural practices.

The degradation of environmental services (e.g. pest population control, erosion protection, water retention) [7] might also affect productivity [5]. However, so far no hard evidence exists regarding this relation. This apparent lack of evidence might be owed to the weak dependence on environmental services of a highly subsidized agriculture, and/or the fact that the role of these services has not yet been properly investigated.

Cattle ranching intensification [24] might be causing [7] and [15] through the modification of nutrients cycles, fodder cultivation, and the deposition of organic and inorganic wastes. These effects have not been extensively studied in Argentina. However, there is wide support from international studies for this hypothesis (Díaz-Zorita 2001). For instance, there is strong evidence of higher phosphorus unbalances in cattle ranching areas compared with areas under agriculture with adequate fertilization practices. 
Finally, the experts proposed three hypotheses about the linkages between agriculture and atmospheric gas emissions. First, cattle ranching intensification [24] might be reducing methane emissions [18]. Extensive cattle ranching generates more methane than crop growing through the livestock's metabolic processes, and more carbon dioxide due to the management practice of burning pastures (Viglizzo et al. 2006). Second, higher agriculture productivity [5] and no tillage might be diminishing carbon emissions [19] via increasing carbon sequestration by crops and the lower fossil fuel consumption of downscaled tillage operations (Viglizzo et al. 2003). In extra-Pampean regions, however, the conversion of forests into agriculture is diminishing carbon sequestration and, more importantly, releasing stored carbon (Paruelo et al. 2005). In any case, the Pampas agroecosystems would still be a net carbon emitter. Third, input-oriented technologies [2] might be generating higher nitrous oxide emissions [17] due to soil management practices in the case of soybean and fodder. In order to test these hypotheses, an overall balance of energy and material flows should be performed, including fossil fuel consumption and the emission derived from the production of herbicides, pesticides and seeds.

\subsection{Social and population changes related with agriculturization}

Most social and population changes caused by agriculturization are derived from the transformation of agricultural practices [9]. The adoption of process-oriented technologies (i.e. no-till soybean monoculture) requires fewer jobs for seeding and harvesting tasks [12] due to the intense use of agrochemicals. For example, no-tillage employs one permanent worker and 15 day's wages per each 270 ha. In contrast, conventional tillage requires one worker and 19 day's wages for each 189 ha (Blanco 2005). However, there are major controversies regarding net job creation (Rodríguez 2006). The jobs lost in cultivation tasks might be partly, or totally, compensated with the creation of new jobs from cattle ranching intensification, larger areas under cultivation, and new activities across the production chain of transport, storage of seeds, and vegetal oil industry.

Transformation of cropping practices [9] also leads to rural exodus at the farm level [13]. Urban population in the Pampas and, particularly, in the extra-Pampean regions is rapidly growing (Table 3). On the contrary, rural population (in settlements under 2,000 inhabitants) has been concentrating in larger settlements and decreasing since 1940. However, this trend should be interpreted as a historical process not directly caused, although probably accelerated, by agriculturization (Reboratti 2005).

Finally, Pampean cities are expanding in terms of area [14]. Immigrants come from rural exodus [13], or foreign countries [16]. Sometimes urban expansion is caused by the creation of private urbanizations ranging from 300 to 800 ha. Urbanization often occurs at the expense of highly productive agricultural land [25]. It has been estimated that the growth of the Metropolitan Area of Buenos Aires encroaches up to around 45 ha of agriculture land per year (Morello et al. 2000). Furthermore, urbanization demands soil materials for industries and the construction sector. Consequently, urban expansion [25] implies a reduction of the area under cultivation [3], even if it is not a very significant one.

\section{Discussion: Is agriculturization sustainable?}

Sustainability is an emergent property whose characterization requires the integration of multiple perspectives. Our results show how the collective representation of a causal 
Table 3 Change in urban and rural populations in Pampean and extra-Pampean provinces

\begin{tabular}{|c|c|c|c|c|}
\hline & & \multicolumn{2}{|l|}{ Population } & \multirow{2}{*}{$\begin{array}{l}\text { Percentage } \\
\text { of change }(\%)\end{array}$} \\
\hline & & 1991 & 2001 & \\
\hline \multirow{4}{*}{$\begin{array}{l}\text { Pampean provinces (Buenos Aires, } \\
\text { Córdoba, Entre Ríos, Santa Fe) }\end{array}$} & Urban $^{\mathrm{a}}$ & $18,197,965$ & $19,678,115$ & 8.1 \\
\hline & Rural total & $1,592,627$ & $1,376,738$ & -13.5 \\
\hline & Rural high-density $^{\mathrm{b}}$ & 528,568 & 573,141 & 8.4 \\
\hline & Rural sparse ${ }^{c}$ & $1,064,059$ & 803,597 & -24.5 \\
\hline \multirow{4}{*}{$\begin{array}{l}\text { Extra-Pampean provinces } \\
\text { (Chaco, Corrientes, } \\
\text { Formosa, Santiago del Estero) }\end{array}$} & Urban $^{\mathrm{a}}$ & $1,843,647$ & $2,433,522$ & 32.0 \\
\hline & Rural total & 862,025 & 772,931 & -10.3 \\
\hline & Rural high-density $^{\mathrm{b}}$ & 141,401 & 149,127 & 5.5 \\
\hline & Rural sparse $\mathrm{c}^{\mathrm{c}}$ & 720,624 & 623,804 & -13.4 \\
\hline
\end{tabular}

${ }^{a}$ more than 2,000 inhabitants

b concentrated in settlements of less than 2,000 inhabitants

$\mathrm{c}$ in farms or small colonies

Source: INDEC Census, 2001

diagram may provide a broad picture of the multiple dimensions and possible interrelations associated with the sustainability or unsustainability of complex processes, such as agriculturization. The factors represented in Fig. 2 can be grouped into four subsystems or dimensions: productive-technological (factors 1, 2, 3, 4, 5, 11, 22, 23, 24, 25); economicinstitutional $(6,8,10,21)$; social $(9,12,13,14,16,20)$; and environmental $(7,11,15,17$, $18,19)$. Figure 7 shows the causal connections identified among subsystems.

It is important to note the small number of feedbacks in Fig. 2. All the causal chains are one-way, with two exceptions: the relationships between Productivity [5] and Degradation of aquifers and soils [15], representing a negative (self-regulating) feedback; and between Technology inputs and productive strategies [2], Concentration of production and management [1], and Changes in the vision of producers [23], representing a positive (selfreinforced) feedback. On the one hand, the lack of feedbacks might partly be explained by the limited time for building the diagram, or by a perceptual bias of the experts selected.

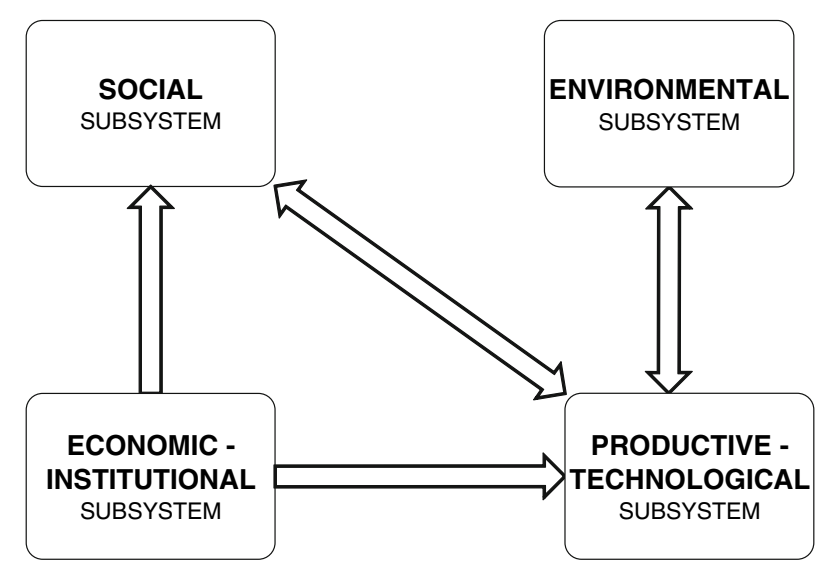

Fig. 7 Subsystems and interrelations from the agriculturization causal diagram in the Argentine Pampas and extra-Pampean regions 
However, neither is likely to be the case given that the lack of feedbacks occurred in the two subgroups working independently, and also in the diagram previously developed by Rabinovich and Torres (2004) without the workshop's time constraints. On the other hand, the apparent lack of feedbacks could also be explained by the possibility that some causal relations are not yet noticeable, although they might arise in the future.

Even though the experts agreed on a common multi-causal representation, there was no consensus regarding the sustainability diagnosis of the process of agriculturization. Two opposing views emerged during the e-mail discussions after the workshop. One group of experts concluded that, in the Pampas, agriculturization currently does not show symptoms of unsustainability, even if some significant threats might emerge in the mid- and longterm. This same group claimed that we lack enough knowledge for determining whether agriculturization is sustainable in the extra-Pampean regions.

Another group of experts argued that, in the Pampas, a conclusive assessment about the sustainability or unsustainability of agriculturization could not be yet carried out because there are symptoms pointing in both directions. For instance, no-till agriculture might have contributed to the advancement of environmental sustainability at the local and unit-ofproduction scales, but there are important threats to sustainability at the regional scale that thwart these local achievements. In addition, this second group claimed that agriculturization is evidently unsustainable in the extra-Pampean region.

Despite this lack of consensus in the diagnosis of sustainability, the broad picture provided in Fig. 2 still permits the identification of some root causes linked to the proximal threats to sustainability within the environmental, social, population, economic, institutional, and techno-productive dimensions.

\subsection{Threats to environmental sustainability}

Environmental sustainability is directly threatened by the following proximate technoproductive factors: soybean monoculture, expansion of the area under cultivation, and the intensification of cattle ranching (Fig. 2). However, there are multiple uncertainties and numerous disagreements among experts regarding the magnitude of these impacts. A key issue is the extent of the positive effects of no-tillage to compensate for the negative effects of expansion, intensification and the ecological simplification of agroecosystem. However, these negative effects are far more evident in the case of the extra-Pampean regions. This suggests that a transfer of the Pampean agriculturization model to these regions, without substantial modifications and precautions, would be highly problematic.

\subsection{Threats to agro-productive sustainability}

Agriculturization has evolved in Argentina within an institutional context characterized by a relative absence of public actors, and a strong presence of international private actors and market rules. Some locally based private actors have successfully adapted to this context by adopting new organization strategies (often linked to technological packages and specific crops). These adaptive strategies are effective for the endurance and thriving of large and middle-sized agribusinesses in the short-term. However, the predominance of entrepreneurial logics may favor the future migration of private investments towards other economic sectors in response to plausible unfavorable variations in the relative profitability of agriculture. Consequently, strategies based exclusively on private sector adaptive 
responses do not guarantee the long-term sustainability of the agro-productive system against economic cycles and market or climate fluctuations.

Macro-economic vulnerability of the agro-productive system has increased due to the specialization of production in a small number of export-oriented commodities. Cereals, oilseeds and cattle account for about $80 \%$ of exports, of which soybeans and its agroindustrial complex represent $50 \%$. The Argentine dependence on agricultural exports is much higher than in neighboring countries such as Brazil.

Beyond markets and policies, the sustainability of the agro-productive system is threatened by regional and global biophysical alterations. At the regional scale, soil erosion is still a threat even if it is being partially compensated by technological adaptations within the very production system (e.g. no-till agriculture, fertilizations and adequate rotation systems). Other significant threats include the plausible reversion of the current wet climate towards a drier epoch, and the increased risk of plagues and herbicide-tolerant weeds associated with soybean monoculture.

\subsection{Threats to social sustainability}

Entrepreneurial logic is not always in line with the long term interests of society as a whole. In addition, social sustainability in the Pampas and, particularly, in extra-Pampean areas is threatened by socio-distributive problems manifested by the low values of sociodevelopment indexes such as poverty indicators, literacy, health, and the Unsatisfied Basic Needs Index. These problems are part of a global trend, but aggravated in the case of the Pampean regions by the concentration of production and management, and the adoption of technologies less intensive in human work. The fact is that the increase in production does not appear to be leading to improvements of socio-development indexes (Paruelo and Oesterheld 2004), although this issue needs to be assessed more rigorously. Threats over social sustainability are more perceptible in extra-Pampean regions due to the clash between two very dissimilar production models (Reboratti 2005).

A second type of threats to social sustainability has its origins in territorial unbalance and political weakening of rural communities due to the increasing political, social, and economic relative power of urban areas. In addition, rural centers are losing the social networks of actors which used to provide diversified services for small and medium farmers, including many family owned businesses.

The dependency of the Argentine economy upon agriculture export taxes is a factor indirectly causing social unsustainability by enforcing political support to intensive agriculture regardless of its social impacts in the Pampas and extra-Pampean regions. Revenues from agriculture export taxes are invested in national plans of social assistance. However, only a small amount of the assistance is used to tackle the environmental and social impacts occurring in the very rural areas in which these revenues are ultimately generated.

\section{Policy recommendations and conclusion}

In terms of policy recommendations, it is important to note that the weakness of the public sector and the absence of agricultural policy [21] are "source" factors directly affecting the techno-productive dimension, which in turn influence the environmental and social dimensions. Consequently, recovering a stronger role for the public sector is crucial for designing integrated actions simultaneously impinging on several factors of the causal 
network of agriculturization. This is especially needed in the extra-Pampean regions, in which land planning and environmental protection are urgent for preventing the indiscriminate conversion of key ecosystems into agriculture.

In already cultivated areas, integrated policies should promote a farming model based in the combination of zero-tillage, adequate rotation of crops, and nutrient replenishment through fertilization. These policies should also include measures aimed at strengthening rural communities through investments in public services and local governance. A key strategy is to influence the terms and conditions of land exploitation contracts between land owners, tenants, and operators of cultivation tasks. These terms and conditions should harmonize the tenant's income with the preservation of soil fertility by requiring sustainable combinations of production techniques, tenure costs, and duration of contracts.

The causal diagram presented here should be considered as a work-in-progress and not as a definitive, hegemonic, unambiguous, or exclusive view. It is important to note that the outcome might have been different if the perspectives from other experts would have been included. Unfortunately, the inclusion of further perspectives, although desirable, would have made the process longer and more expensive. Our methodology sought to control the constraints of not including additional perspectives by splitting the group of experts into two subgroups and checking whether each subgroup came up with very different diagrams. In this case, the two subgroups produced reasonably similar diagrams that were easily merged.

One of the main points of this paper is to illustrate how the collaborative characterization of cause-and-effect networks facilitates agreement among experts, from diverse disciplines, regarding what is happening and why. This characterization also provides the opportunity to identify the main uncertainties and needs for future research, and to make the different experts' positions and points of dissent more transparent.

The paper also shows the highly contentious nature of sustainability in the Pampas and extra-Pampean regions. In the context of scientific and political debates, scientific facts are sometimes manipulated to make them conform to competing political or moral claims. Disciplinary perspectives offer the possibility to deliver their clients the relevant facts they need for supporting pre-determined decisions or to gain advantage in political debates. This is particularly acute in sustainability debates given the high complexity and multidimensionality of the concept. Interdisciplinary discussion can be, therefore, considered as a precondition for sound sustainability research. In the case presented here, an agreement on what is happening was reached albeit not rendering consensus on the assessment of whether it is sustainable or not. Nonetheless, the exercise of building a joint causal diagram was useful for linking the piece-meal disciplinary facts, brought in from all fronts, into a comprehensive and coherent picture.

Acknowledgments This material is based upon work supported by the U. S. National Science Foundation under Biocomplexity in the Environment Grant No. 0410348. This article is also based on research supported in part by a grant from the U.S. National Oceanic and Atmospheric Administration's Climate Program Office (formerly the Office of Global Programs) through the Environment, Science and Development Program for the Knowledge Systems for Sustainable Development Project. Part of the ideas developed in this paper was partially published in Serie Medio Ambiente y Desarrollo 118 of the United Nations Economic Commission for Latin America and the Caribbean.

\section{References}

AACREA (2001). Series de Precios Agropecuarios. Retrieved June 12, 2007, from Asociación Argentina de Consorcios Regionales de Experimentación Agrícola Web site: http://www.aacrea.org.ar/soft/ series.htm. 
Bilenca, D. (2000). Los agroecosistemas y la conservación de la biodiversidad: El caso del pastizal Pampeano. Gerencia Ambiental,67, 566. Retrieved May 13, 2007, from http://www.caece.edu.ar/ investigacion/documentos/BIOPAMP2.DOC.

Bilenca, D., \& Kravetz, F. O. (1995). Daños a maíz de roedores en la Región Pampeana (Argentina) y un plan para su control. Vida Silvestre Neotropical, 4, 51-57.

Bisang, R. (2003, November). Diffusion process in networks: The case of transgenic soybean in Argentina. Paper presented at the First Globellics Conference, Río de Janeiro.

Blanco, M. (2005). La incorporación de la agricultura conservacionista en la region pampeana. Debate Agrario Análisis y Perspectivas, 3, 141-157.

Blake, R., Fereres, E., Henzell, T., \& Powell, W. (2002). CienciaHoy, 12(70), 31-51.

Branford, S. (2004). Argentina's bitter harvest. New Scientist, 17th April, 40-43.

Carolan, M. S. (2005). Barriers to the adoption of sustainable agriculture on rented land: An examination of contesting social fields. Rural Sociology, 70, 387-413.

Casas, R. R. (2005). Efectos de la intensificación agrícola sobre los suelos. CienciaHoy, 15(87), 44-45.

Costa, J., Massone, H., Martínez, D., Suero, E., Vidal, C., \& Bedmar, F. (2002). Nitrate contamination of a rural aquifer and accumulation in the unsaturated zone. Agricultural Water Management, 57, 33-47.

Díaz-Zorita, M. (2001). Ciclado de nutrientes en sistemas pastoriles. Retrieved February 10, 2007, from Sitio Argentino de Producción Animal Web site: http://www.produccionbovina.com/suelos_ ganaderos/52-ciclado_nutrientes.htm.

Díaz-Zorita, M. (2005). Cambios en el uso de pesticidas y fertilizantes. CienciaHoy, 15(87), 28-29.

Díaz-Zorita, M., Duarte, G. A., \& Grove, J. H. (2002). A review of no-till systems and soil management for sustainable crop production in the subhuumid and semiarid Pampas of Argentina. Soil \& Tillage Research, 65, 1-18.

FAO (2004). Fertilizer use by crop in Argentina. Food and Agriculture Organization of the United Nations. Rome: Land and Plant Nutrition Management Service.

Ferraro, D. O., Ghersa, C.M., \& Sznaider, G.A. (2003). Evaluation of environmental impact indicators using fuzzy logic to assess the mixed cropping systems of the Inland Pampa, Argentina. Agriculture, Ecosystems \& Environment, 96, 1-18.

Flores, C. C., \& Sarandon, J. (2002). Racionalidad económica versus sustentabilidad ecológica? El ejemplo del costo oculto de la pérdida de fertilidad del suelo durante el proceso de Agriculturización en la Región Pampeana argentina. Revista de la Facultad de Agronomía, La Plata, 105(1), 52-67.

Ghersa, C. M., \& Ghersa, M. A. M. (1991). Cambios Ecológicos en los Agroecosistemas de la Pampa Ondulada. Efectos de la Introducción de la Soja. Ciencia e Investigación, 5, 182-188.

Hall, A. J., Rebella, C. M., Ghersa, C. M., \& Culot, J. P. (1992). Field crop systems of the Pampas. In: C. J. Pearson (Ed.), Ecosystems of the world (pp. 413-430). Amsterdam: Elsevier.

Irurtia, C. \& Mon, R. (2000, October). Impacto de la erosión hídrica en la producción de granos en Argiudoles típicos de la pampa ondulada. Paper presented at the 11th. Conference of the International Soil Conservation Organization, Buenos Aires.

Jergentza, S., Mugnib, H., Bonetto, C., \& Schulzc, R. (2005). Assessment of insecticide contamination in runoff and stream water of small agricultural streams in the main soybean area of Argentina. Chemosphere, 61, 817-826.

Kates, R. W., Clark, W. C., Corell, R., Hall, J. M., Jaeger, C. C., Lowe, I., McCarthy, J. J., Schellnhuber, H. J., Bolin, B., Dickson, N. M., Faucheux, S., Gallopin, G. C., Gruebler, A., Huntley, B., Jäger, J., Jodha, N. S., Kasperson, R. E., Mabogunje, A., Matson, P., Mooney, H., Moore III, B., O’Riordan, T., \& Svedin, U. (2001). Sustainability science. Science, 292, 641-642.

Leteinturier, B., Herman, J.L., Longueville, F., Quintin, L., \& Oger, R. (2006). Adaptation of a crop sequence indicator based on a land parcel management system. Agriculture, Ecosystems \& Environment, 112, 324-334.

Lüdeke, M. K. B., Petschel-Held, G., \& Schellnhuber, H. J. (2004). Syndromes of global change: The first panoramic view. Gaia, 13(1), 42-49.

Maddonni, G., Urricariet, S., Ghersa, C., \& Lavado, R. (1999). Assessing soil quality in the Rolling Pampa, using soil properties and maize characteristics. Agronomy Journal, 91, 280-287.

Manuel-Navarrete, D., \& Gallopín, G. (2007). Integración de políticas, sostenibilidad y agriculturización en la pampa argentina y áreas extrapampeanas. Seminars and Conferences Series 50. Santiago de Chile: ECLAC.

Manuel-Navarrete, D., Gallopín, G., Blanco, M., Díaz-Zorita, M., Ferraro, D., Herzer, H., Laterra, P., Morello, J., Murmis, M. R., Pengue, W., Piñeiro, M., Podestá, G., Satorre, E. H., Torrent, M., Torres, F., Viglizzo, E., Caputo, M. G., \& A. Celis (2005). Análisis sistémico de la agriculturización en la pampa húmeda argentina y sus consecuencias en regiones extra-Pampeanas: sostenibilidad, brechas de conocimiento, e integración de políticas. Environment and Development Series 118. Santiago de Chile: ECLAC. 
Manuel-Navarrete, D., Gómez, J. J., \& Gallopín, G. (2007). Syndromes of sustainability of development for assessing the vulnerability of coupled human-environmental systems. The case of hydrometeorological disasters in Central America and the Caribbean. Global Environmental Change, 17(2), 207-217.

Messina, C. D. (1999). El Niño Southern oscillation y la Productividad de Cultivos en la Zona Pampeana: Evaluación de Estrategias para Mitigar el Riesgo Climático. Dissertation, Universidad de Buenos Aires.

Miglioranza, K., Aizpun de Moreno, J., \& Moreno, V. (2003). Dynamics of organochlorine pesticides in soils from a southeastern region of Argentina. Environmental Toxicology and Chemistry, 22, 712-717.

Morales, C. (2001). Las nuevas fronteras tecnológicas: promesas, desafíos y amenazas de los transgénicos. Productive Development Series, 101. Santiago de Chile: ECLAC.

Morello, J., Buzai, G., Baxendale, C., Rodríguez, A., Matteucci, S., Godagnone, R., \& Casas, R. (2000). Urbanization and the consumption of fertile land and other ecological changes: The case of Buenos Aires. Environment and Urbanization, 12(2), 119-131.

Paruelo, J. M., Guerschman, J. P., \& Verón, S.R. (2005). Expansión agrícola y cambios en el uso del suelo. CienciaHoy, 15(87), 14-23.

Paruelo, J. M., \& Oesterheld, M. (2004). Patrones espaciales y temporales de la expansión de Soja en Argentina. Relación con factores socio-económicos y ambientales. Retrieved October 24, 2007, from Universidad de Buenos Aires, Facultad de Agronomía Web site: http://www.agro.uba.ar/users/lart/ bancomundial/INFORME_final.pdf.

Pengue, W. (2005). Agricultura industrial y transnacionalización en América Latina. Mexico City: United Nations Environmental Programe.

Piñeiro, M., \& Villarreal, F. (2005). Modernización agrícola y nuevos actores sociales. CienciaHoy, 15(87), 32-36.

Qaim, M., \& Traxler, G. (2005). Roundup ready soybeans in Argentina: farm level and aggregate welfare effects. Agricultural Economics, 32, 73-86.

Rabinovich, J., \& Torres, F. (2004). Caracterización de los síndromes de sostenibilidad del desarrollo: El caso de Argentina. Seminars and Conferences Series 38. Santiago de Chile: ECLAC.

Reboratti, C. E. (2005). Efectos sociales de los cambios en la agricultura. CienciaHoy, 15(87), 52-61.

Rodríguez, J. (2006). Los complejos agroalimentarios y el empleo: Una controversia teórica y empírica. Realidad Económica, 218, 107-135.

SAGPyA (2002). Censo Nacional Agropecuario 2002, Retrieved May, 2007, from National Institute of Statistics and Census of Argentina Web site: http://www.indec.mecon.gov.ar/agropecuario/cna.asp.

SAGPyA (2005). Estadísticas Agrícolas. Retrieved May, 2007, from Secretaría de Agricultura, Ganadería, Pesca y Alimentos Web site: www.sagpya.gov.ar.

Salvador, C. (2001). The environmentally positive aspects of the agrochemical industry in Argentina. In O. T. Slbrig, R. Paarlberg, \& F. di Castri (Eds.), Globalization and the rural environment (pp. 201-216). Cambridge: Harvard University Press.

Satorre, E. H. (2001). Production systems in the Argentine Pampas and their ecological impact. In O. T. Slbrig, R. Paarlberg, \& F. di Castri (Eds.), Globalization and the rural environment (pp. 81-102). Cambridge: Harvard University Press.

Satorre, E. H. (2005). Cambios tecnológicos en la agricultura actual. Ciencia Hoy, 15, 24-31.

Sierra, E. M., Hurtado, R. H., \& Spescha, L. (1994). Corrimiento de las isoyietas anuales medias decenales en la región Pampeana 1941-1990. Revista de la Facultad de Agronomía, 14(2), 139-144.

Trigo, E. (2005). Consecuencias Económicas de la Transformación Agrícola. CienciaHoy, 15, 46-51.

Trigo, E. J., \& Cap, E. J. (2003). The impact of the introduction of transgenic crops in Argentinean agriculture. AgBioForum, 6(3), 87-94.

Viglizzo, E. F., \& Frank, F. C. (2006). Land use options for Del Plata Basin in South America: Tradeoffs analysis based on ecosystem service provision. Ecological Economics, 57, 140-151.

Viglizzo, E. F., Frank, F. C., Bernardos, J., Buschiazzo, D. E., \& Cabo, S. (2006). A rapid method for assessing the environmental performance of commercial farms in the Pampas of Argentina. Environmental Monitoring and Assessment, 117, 109-134.

Viglizzo, E. F., Lértora, F., Pordomingo, A. J., Bernardos, J. N., Roberto, Z. E., \& Del Valle, H. (2001). Ecological lessons and applications from one century of low external-input farming in the Pampas of Argentina. Agriculture, Ecosystems \& Environment, 83, 65-81.

Viglizzo, E. F., Pordomingo, A. J., Castro, M. G., \& Lértora, F. (2003). Environmental assessment of agriculture at a regional scale in the pampas of Argentina. Environmental Monitoring and Assessment, 87, 169-195.

Viglizzo, E. F., Roberto, Z. E., Lértora, F. A., Gay, E. L., \& Bernardos, J. N. (1997). Climate and land use change in field-crop ecosystems of Argentina. Agriculture, Ecosystems \& Environment, 66, 61-70. 